\title{
Online courses in times of pandemic: ESP and applied English classes at Université Paris 8
}

Basculer au tout en ligne en période de pandémie: anglais de spécialité et LEA à

l'Université Paris 8

\section{Gwen Le Cor and Margaux Coutherut}

\section{OpenEdition}

\section{Journals}

Electronic version

URL: http://journals.openedition.org/asp/6481

DOI: 10.4000/asp.6481

ISSN: 2108-6354

\section{Publisher}

Groupe d'étude et de recherche en anglais de spécialité

\section{Printed version}

Date of publication: 1 November 2020

Number of pages: 7-17

ISSN: 1246-8185

\section{Electronic reference}

Gwen Le Cor and Margaux Coutherut, "Online courses in times of pandemic: ESP and applied English classes at Université Paris 8", ASp [Online], 78 | 2020, Online since 01 November 2020, connection on 05 March 2021. URL: http://journals.openedition.org/asp/6481 ; DOI: https://doi.org/10.4000/asp. 6481

This text was automatically generated on 5 March 2021.

Tous droits réservés 


\section{Online courses in times of pandemic: ESP and applied English classes at Université Paris 8}

Basculer au tout en ligne en période de pandémie : anglais de spécialité et LEA à l'Université Paris 8

Gwen Le Cor and Margaux Coutherut

\section{Avant-Propos}

Dans ce compte rendu, Gwen Le Cor et Margaux Coutherut livrent un état des lieux de la situation dont les enseignants du département LEA de l'Université Paris 8 ont fait l'expérience lors de ce printemps 2020 tout à fait hors norme. Toutefois, nombre d'éléments de cet état des lieux valent bien au-delà de cette seule filière et de cette seule université puisque le basculement en ligne brutal et massif des activités d'enseignement que les auteurs décrivent ici a concerné l'ensemble de la communauté universitaire française. Or, comme elles le soulignent très justement, il y a un monde entre la conception raisonnée et planifiée de cours destinés à l'enseignement à distance ou en mode hybride et la migration en ligne, dans l'urgence, de contenus pensés pour un enseignement en présentiel.

2 Leur compte rendu, fondé sur l'analyse des réponses à un questionnaire soumis à leurs collègues du département LEA de l'Université Paris 8, montre que cette migration s'est traduite par des pratiques extrêmement variables selon le degré de maîtrise des outils technologiques de ces derniers. Cependant, il permet d'abord et avant tout de prendre la mesure des difficultés de tous ordres rencontrées par les étudiants en cette période inédite, et du défi qu'essayer d'y apporter des réponses a pu présenter pour leurs enseignants. Les auteurs relèvent ainsi que les adaptations rendues nécessaires par la situation se sont accompagnées d'une transformation assez radicale du rôle de ceux-ci. Enfin, elles attirent l'attention sur deux points qui mériteraient d'être développés au-delà de ce que permet un compte rendu de ce type, à savoir l'impact du basculement dans l'enseignement à distance sur la fonction sociale de l'université, et les 
questions d'ordre éthique que ce type d'enseignement soulève dans un contexte de crise sanitaire majeure. (Perrine Ciraud-Lanoue, Université de Limoges)

But even here, at the level of virtual reality and the internet, we should remind ourselves that, in

the last decades, the terms "virus" and "viral" were mostly used to designate digital viruses that infected our web-space and of which we were not aware, at least not until their destructive power

(say, of destroying our data or our hard drive) was unleashed. (Žižek, 2020b: 44)

\section{Introduction}

3 As countries went into lockdown, the Covid-19 pandemic started to affect every single aspect of our lives. We all stood in shock as the world stopped in what seemed like a post-apocalyptic fiction, facing stay at home orders and other public health emergency laws. For some it also meant increased vulnerability and soaring anxiety levels about what might lie ahead. As Slavoj Žižek explains in the "Posts from the Pandemic" series on the Critical Inquiry blog:

We are caught in a triple crisis: medical (the epidemic itself), economic (which will hit hard whatever the outcome of the epidemic), plus (not to underestimate) the mental health - the basic coordinates of the life-world of millions and millions are disintegrating, and the change will affect everything, from flying during holidays to everyday bodily contacts. (Žižek 2020a)

Physical distancing also had a direct impact on higher education and pedagogy. As schools and universities across the world closed one after the other ${ }^{1}$ in a "collective endeavor to flatten the curve" (Dumitrescu \& Smith 2020), online teaching and virtual classrooms became the new mantra. The shift from on-site teaching to online teaching was sudden, if not brutal. In France, it occurred on March 16, 2020 with no forewarning, when the president announced that all schools and universities would close "until further notice." We would like to dwell here on what this abrupt suspension of oncampus courses entailed for us at Université Paris 8, as ideal remote teaching scenarios immediately clashed with the reality of the students' precarious living and learning environments.

Most of us had been using digital tools before the pandemic, whether to build courses or to supplement them (adding resources, allowing students to submit an assignment, providing feedback or for creating peer-review sessions for assignments ...). We are not technophobic, far from it, one of the authors of this paper wrote about e-learning and computer environments (Le Grand et al. 2015). Yet, what occurred here is of a totally different nature. Courses that were implemented for classroom interaction had to go digital, almost overnight. Professors and instructors soon realized there is a profound discrepancy between designing a remote learning or hybrid course, and having to instantly adapt on-campus courses to bring them online. ${ }^{2}$

We started experiencing firsthand what Bernard Stiegler theorized as the pharmacological principle of the digital: "The digital is precisely a pharmakon, a poison and a remedy. Our era is starting to see more and more clearly the emergence of toxicity" (Stiegler 2016: 158). ${ }^{3}$ In 2016, Stiegler urged universities to "take over the 
digital, for it is a matter of their survival. The university will be the promulgator of knowledge; it will not be simply the dispenser of education. Put another way, it will become digital or it will no longer exist." (Stiegler 2016: 62). In 2020, Covid-19 introduced a shift towards online teaching at the pace of the pandemic, that is, without providing any time for transition and critical thought. In this paper, we would like to point out how, in our experience, the poisonous aspects of the digital were interwoven with both pandemic related time-constraints and specific territorial vulnerabilities that, in turn, came into play in the pedagogical decisions we had to make.

\section{Institutional learning environment and personal learning environments}

7 Let us start at the end of the lockdown period, with a questionnaire sent in May 2020 to all faculty members in the applied languages department. The questionnaire consisted of closed-ended questions (multiple response) and open-ended questions about pedagogical practices during the lockdown period. It was sent to 67 people and we received 36 answers. The questions were written in French and concerned the following topics:

-What tools did you use for remote teaching during the lockdown?

- Did it work well?

-What problems did you encounter with remote learning/teaching?

- What problems did your students face? (technical, personal, sanitary ...)

-If the sanitary crisis continues, what tools will you use next year?

At Paris 8 students are familiar with the Moodle learning platform. ${ }^{4}$ The authors of this paper, for instance, had been using it regularly in all their classes before the crisis. Moodle is an institutional learning management system, and, as all institutional platforms, it is designed to "provide access to learning resources in a structured way (content management function), to manage the registration of learners in courses and to monitor learners' activities and results on the platform." (Peter et al. 2011: \$2.1, our translation). It thus provides the backbone required for information structuring and exchange. As we became "online instructors/professors", our university IT support added several tools and encouraged the use of two videoconferencing systemsBigBlueButton and RendezVous Renater-to design our virtual classrooms and move online. Yet, what quickly became obvious was that the toxicity of an abrupt shift online prevailed.

9 Neither students nor faculty were prepared for the unexpected viral storm that took us online. To the question "Did remote teaching work well?", only 6 faculty members answered "Yes", 5 answered "No" and 25 had "mixed feelings" about it. Professors used the tools they mastered best while venturing into new environments: 18 faculty members mentioned using videoconferences (BBB, Zoom or Skype). Seventeen professors said that they put their brochures on Moodle, a solution that bans interactivity. One faculty member explained that more adapted platforms such as Teams, Zoom or Webex should be offered by our university. ${ }^{5}$ Twenty eight professors/ instructors decided to communicate with their students by email only. A few faculty members mentioned the use of WhatsApp or phones (for oral expression classes). Others used Dropbox and Google Drive. One professor filmed himself and put the videos on YouTube. Different types of problems emerged: the questionnaires mentioned issues 
with their internet connection (this appeared in 7 questionnaires), the complexity of online teaching with large groups of students (in 15 questionnaires), 8 faculty members explained that they did not have the digital skills needed for remote learning, and 15 others that students were not receptive to digital learning or gave no news at all during lockdown. Several faculty members voiced ethical concerns linked to student assessment and evaluation strategies during the health crisis.

Above all, the questionnaires revealed that our students had to face different types of problems linked to their living and learning environments; and the emails received both by faculty members and by the heads of the applied languages department confirmed it. As one instructor wrote, "Unfortunately, I have lost many students along the way during the lockdown" (our translation).

11 The first poisonous aspect emphasized was that students did not have suitable devices for effective remote learning (this problem emerged in 24 questionnaires out of 36), as this call for help underscores:

Good morning Mrs. Y

This is X Y, a second year student in LEA, I am writing to you to ask for help during

this lockdown period. Indeed, you know very well that in these moments, we need computer equipment to be able to follow our courses and especially to do our exams in the best conditions.

I am writing to you because I really need it.

Thanks. Best regards (our translation)

Not only did our students lack digital equipment but, they found themselves having to deal with food insecurity issues after having lost their part-time (sometimes full-time) jobs. In an email sent on June $8,2020,{ }^{6}$ we were informed that by May 27 , our university had granted more than $€ 740,000$ worth of aid to alleviate the burden on students:

-2,300 food vouchers worth $€ 100$ had been distributed, for a total amount of $€ 218,500$

- 240 computers had been given to students, for a total amount of $€ 81,216$ (the mail spoke of

"digital insecurity")

- 4441,120 had been allocated to students directly.

\section{Interface and bandwidth}

Digital and food insecurity were not the only issues. Some students share a computer with their entire family. A teaching assistant explained, for instance, that one of her students could not take the exam because his younger sister, who was in middle school, had to write a paper and the family only had one computer. Many undergraduates do not own a computer, and thus resorted to working from their phones. Only four days after the beginning of the lockdown period, a student wrote this email: "Good evening Madame X, Sorry to bother you, I just wanted to let you know that it will be difficult for me to have access to your exercises because unfortunately I don't have a computer (and on the phone it is quite complex). Best regards" (our translation). Not only is it difficult to read documents on the small screen of a phone, but writing a text on a phone (for homework or for an exam) is impractical if not downright impossible, as this other student explains:

Unfortunately, I am not able to do my homework due to my physical condition and lack of computer equipment, I live alone in France and I can't afford to buy a computer I tried several times to do my homework on my phone but it does not work either. It always blocks my phone (our translation). 
Technical glitches and readability aside, a change of interface from computer to phone, is not a mere material change. It has a profound impact on the learning process. Media scholars have shown that the interface molds the way information is perceived. In The Interface Effect, Alexander Galloway explains that "an interface is not a thing, an interface is always an effect. It is always a process or a translation." (Galloway 2012: 33). He rejects the idea that an interface is a threshold or a window which would impose "no mode of representation on that which passes through" (op. cit. 40). Conversely for him interfaces "are effects, in that they bring about transformations in material states" (op. cit. vii). An online course designed for computer access will inadequately transfer onto phones. The change of interface (size of screen, portrait or landscape orientation, reduced display, browser...) will induce transformations that need to be taken into account. To quote the 2016 Manifesto for teaching online (see figure 1): "Aesthetics matter: interface design shapes learning."

Figure 1. Screen grab of Manifesto for teaching online 2016

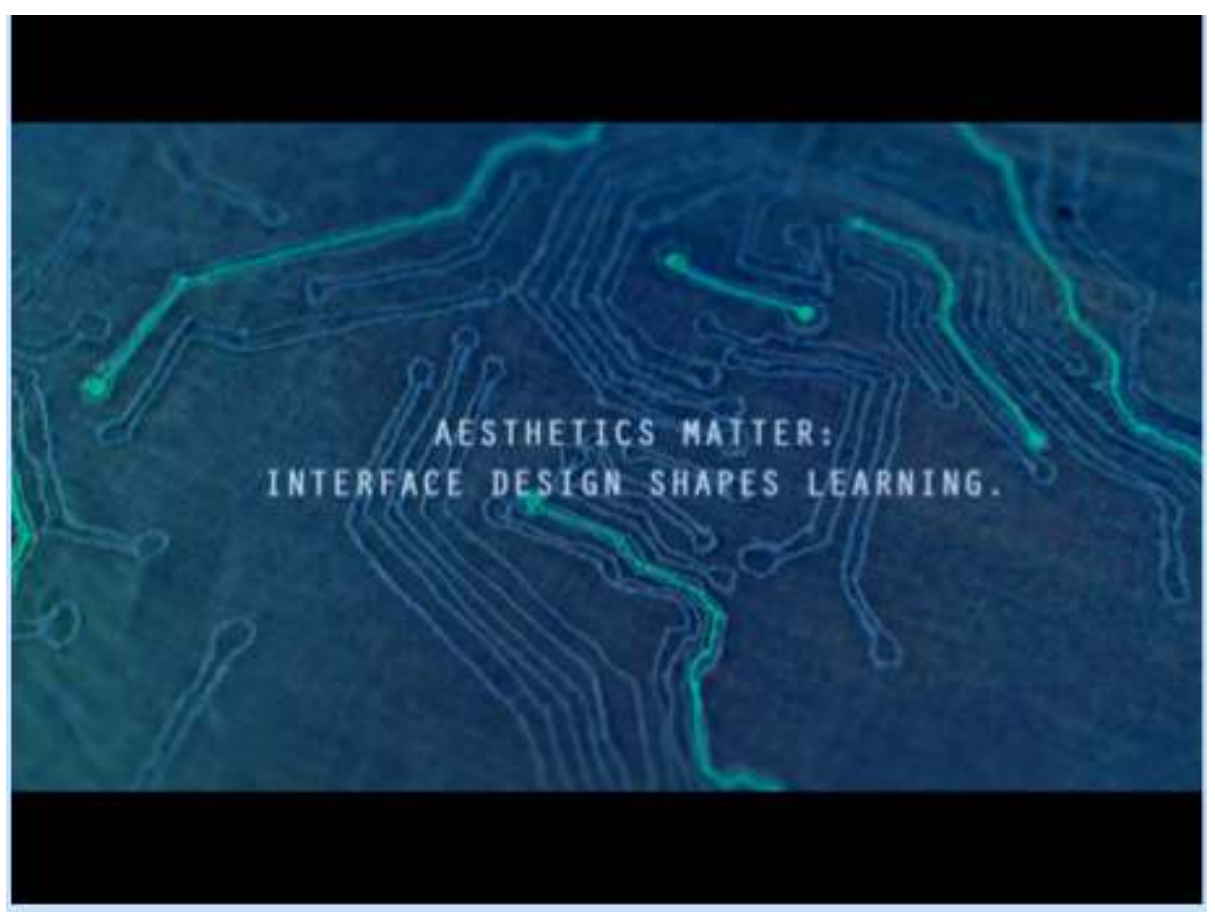

Another problem identified was the inconsistency of the internet connection (12 professors mentioned that their students faced this problem). This either caused disruptions in the live streaming, or led students to deactivate their cameras to avoid saturating the bandwidth. As a result, instructors could not see the student's reactions, thus lacking access to the facial expressions that would have allowed them to appreciate whether or not an idea was grasped. In a recent opinion piece published in Le Monde, several French professors underlined the importance of face-to-face interaction. For them, we "must attract and interest to transmit knowledge." The professor's gaze "must detect the audience's inattention" (Bauer et al. 2020, our translation). 


\section{Socio-geographical vulnerabilities} mortality. According to Santé Publique France, it had an excess mortality of $+262 \%$ in week 15 for instance. ${ }^{8}$ Urban districts "with higher precariousness indicators (unemployment benefit income, poverty rate, social minima in income, little or no graduate in the workforce) and less suitable housing (unworthy housing, household size, overcrowded housing) are more at risk, including when their population is younger" (Goutte, Peran \& Porcher 2020: 14). As a result, our students were literally caught up in the pandemonium. Some were infected by the virus, other saw parents hospitalized and had to take care of younger siblings, ${ }^{9}$ others still had to deal with the daunting challenges of death and grieving. Twenty-two questionnaires emphasized this problem and students' emails showed this harsh reality:

I am writing to you because I have recently lost two members of my family and the funeral of one of them is on Thursday, April 30, the day of the exam, so I would like to know if you would allow me to take the exam on Monday, April 27 from 12 to 2 p.m. instead of Thursday, April 30 from 3 to 5 p.m.

I beg your forgiveness for not answering your emails, I have just seen them, and also for sending you my papers late, I hope you will accept them please because I asked you for some time because I felt sick after I knew I had covid19, I was extremely sick and I lost my brother just after my grandmother. I won't hide it from you, I am depressed. I hope you can understand my situation (our translation).

With their worlds collapsing around them, learning and assessments became inadequate if not altogether obsolete. This traumatic context needs to be taken into account if we are to understand how profound the disruptions to learning were. As Rick Moody -who teaches creative writing at Brown University-contends "Remote learning may be the only feasible way to instruct in this lethal time, but that doesn't mean remote learning represents the best idea in humanist education, or that it is anything like the long-standing model of the liberal arts" (Moody 2020). 


\section{Adapting}

21 Covid-19 took us to uncharted territories, and uncertainty was the guiding principle with which we took our courses fully online. Teaching could not resume as it had in pre-pandemic times. It got intertwined with technical, economic, personal and ethical issues. It was a stark reminder that learning never occurs in a vacuum; it is never disconnected. Rather, it takes place within a learning environment. And here the environment was a Covid-storm.

Knowing the context, we wondered how to adapt remote learning to the constraints. What did the use of phones by our students entail? The first impact was that of internet connectivity and processing speeds. Phones typically have slower processors than computers, and no Ethernet access. They rely on Wi-Fi networks for internet access, making it slower and less reliable. ${ }^{10}$ As a result some of our students could not download videos, nor use video live-streaming. We had to transform the material used and the means of delivery. In both her undergraduate course and in a Masters course on didactics of ESP, one of the authors of the paper opted for a combination of asynchronous assignments and synchronous communication on BigBlueButton without using the face-time feature. Instead she used the chat and professor screen-share features, as well as voice only discussions. Yet, the overwhelming feeling was that the teaching itself was radically transformed. We were isolated in lockdown, losing all possibility of building a community, yet, community building is what defined the prepandemic university system. In their article published in Le Monde, Sylvie Bauer et al. remind us that universities have a social purpose, in that they connect students; "None of this will arise from a totally or partially 'confined' audience" (Bauer et al. 2020, our translation).

The second concern-that of the interface display-had an equally crucial impact. With reduced display sizes, students saw less information at once. Research articles about reading and learning on phones all emphasize the need of gearing the content for mobile displays. In a survey conducted with first-year undergraduates in Japan on "Reading and Grammar Learning through Mobile Phones", Shudong Wang and Simon Smith draw attention to format and motivation. They first stress that "mobile learning content is destined to be short and segmented." (Wang \& Smith 2013: 129). They also point out "the strong association between phones and gaming," and conclude that "if learning of any variety is to be extended onto mobile phones, it must engage students on a level that can compete with free games and social media-a formidable challenge." (op. cit.: 127). Motivation is indeed a key factor in any course. The Covid crisis made this even more palpable.

Ultimately, adaptation was possible because the move online occurred in March, midway through the semester. We could build on what had already started on-campus and rely on the momentum created by pre-pandemic classroom interactions. Content, on the other hand, needed to be tweaked somewhat. For the Masters course in didactics of ESP, we moved away from what was initially planned to discuss the challenges of online teaching/learning. Perhaps the most obvious change was that all our courses relied more heavily than originally intended on the cloud (MOOCs, articles...), turning us into curators of online content and discussion moderators. 


\section{Conclusion}

For B. Stiegler "the digital is a pharmakon with an extraordinary potential for liberation and opening", yet this potential only comes into play "if the rules of design and operation of the platforms are defined" (Stiegler 2015, our translation). This is precisely what was lacking in the abrupt shift online. The toxicity of this shift came, first, from a traumatic lockdown-the empty streets, our retreat into self-isolation, the fear of an unknown illness, the senselessness ${ }^{11}$ of it all. The toxicity also originated, in the case of our students, from specific socio-economic vulnerabilities and digital insecurities. As Satterfield \& Kelle remind us, online education, has "much higher cost barriers" (2017: 266), it thus carries with it the risk of increased inequalities.

Online teaching in times of pandemic is not akin to carefully planned distance learning. Any online learning lowers levels of social interaction, which in turn can decrease motivation (Satterfield \& Kelle 2017: 259), but here, social and physical distancing was a necessity imposed by a virus. It was a medical and political choice, not a pedagogical one. And as such, it had ethical and social implications that, if left unvoiced, become toxic.

\section{BIBLIOGRAPHY}

ALLOA, Emmanuel. 2020. "Coronavirus: A Contingency that Eliminates Contingency". Critical Inquiry, Posts from the pandemic, April 20. Retrieved from <https://critinq.wordpress.com/ 2020/04/20/coronavirus-a-contingency-that-eliminates-contingency/> on 23/06/2020.

BAUER, Sylvie. "Imaginer une université à distance, c'est renoncer à sa fonction sociale". Le Monde, June 19, 2020.

CHAMARET, Cécile. 2020. “Témoignage online Polytechnique”. Enseignement online, Le Libellio, Volume 16, série spéciale Coronam semaine 2, April, 33-36. Retrieved from <http:// lelibellio.com/wp-content/uploads/2020/04/Coronam-2.pdf> on 23/06/2020.

Dumitrescu, Irina \& Caleb SMITH. 2020. “The Demon of Distraction”. Critical Inquiry, Posts from the pandemic, April 22. Retrieved from <https://critinq.wordpress.com/2020/04/22/the-demon-ofdistraction/> on 23/06/2020.

Galloway, Alexander. 2012. The Interface Effect. Malden, MA.: Polity Press.

GOUTTE, Stéphane, Thomas PÉRAN \& Thomas PORCHER. 2020. "Social Inequalities and Vulnerability of population facing the Covid-19: the case of Seine-Saint-Denis in Ile-de-France". Preprint submitted on 20 May 2020. ffhalshs-02613278f

LE GRAND, Bénédicte, Gwen LE COR, Alice ALBANO \& Fatima HARRAk. 2015. "Restitution aux enseignants de l'évaluation des apprentissages dans des EIAH ". Environnement Informatique pour l'Apprentissage Humain, Agadir. 
MOODY, Rick. 2020. “Why Teaching Literary Arts Over Zoom Doesn't Quite Work”. The New Yorker, April 6.

PETER, Yvan, Sabine LEROY \& Eric LEPRÊTRE. 2011 "Intégration des espaces institutionnels et personnels pour l'apprentissage”. Revue STICEF 18. ISSN: 1764-7223. Retrieved from <http:// sticef.org> on $23 / 06 / 2020$.

SATTERFIELD, Debra \& Sebastian KELLE. 2017 "Ethical Issues in Online Education”. In Ahram, T. \& W. Karwowski (Eds), Advances in The Human Side of Service Engineering. Advances in Intelligent Systems and Computing, vol. 494. Springer, Cham. 257-266.

STIEGLER, Bernard. 2010. “The Age of De-proletarianisation: Art and teaching art in post-

consumerist culture". In Corcoran, Kieran \& Carla Delfos (Eds.), ArtFutures Current Issues in Higher Arts Education. Amsterdam: ELIA, 10-19.

STIEGLER, Bernard. 2015. "Numérique, éducation et cosmopolitisme”. Propos recueillis par Paul Audi et Cyril Bedel. Cités 63/3, 13-36. doi:10.3917/cite.063.0013.

STIEGLER, Bernard. 2016. “The Digital, Education, and Cosmopolitanism”. Translated by David Bates. Representations, 134/1, 157-164.

WANG, Shudong \& Simon SMITH. 2013. "Reading and grammar learning through mobile phones". Language Learning \& Technology 17/3, 117-134.

ŽIŽEK, Slavoj. 2020a. “Is Barbarism with a Human Face Our Fate?”. Critical Inquiry, March 18. Retrieved from <https://critinq.wordpress.com/2020/03/18/is-barbarism-with-a-human-faceour-fate/ > on $23 / 06 / 2020$.

ŽIžEK, Slavoj. 2020b. Pandemic! COVID-19 Shakes the World. New York: Polity.

\section{NOTES}

1. The figures given by UNESCO for April 16, 2020 indicate that " $90.1 \%$ of the total enrolled learners" were impacted by these closures, i.e. "1,576,873,546 affected learners". <https:// en.unesco.org/covid19/educationresponse>.

2. See for instance Cécile Chamaret's testimony in Libellio special issue: “I, unfortunately, quickly realized that there is a world of difference between - designing a hybrid course [...]- and having to transform a face-to-face course into an online course, all in one week." (2020: 33, our translation)

3. Stiegler explained this pharmacological principle in detail in "The Age of Deproletarianisation" by linking it to what "Katherine Hayles calls hyper-attention (which is in reality a fragmentation of attention), a destruction of attention." For him: "Like writing, and according to Plato's word, the digital is a pharmakon, that is, at once a poison, a remedy and a scapegoat. Only the digital itself, insofar as it can be a remedy, enables an effective struggle against the poison which it also is, and this is without doubt a key to the 21st century" (Stiegler 2010: 19).

4. According to its promotional website, Moodle "is a learning platform designed to provide educators, administrators and learners with [...] an integrated system to create personalised learning environments." Retrieved from < https://docs.moodle.org/38/en/About_Moodle> on $23 / 06 / 2020$.

5. Our IT service asked us not to use Zoom for teaching or research because of personal data safety problems.

6. The email was sent to all staff and faculty members via<allp8@univ-paris8.fr.> 
7. Preprint submitted on 20 May 2020. Retrieved from < https://halshs.archives-ouvertes.fr/ halshs-02613278/document>.

8. Santé Publique France, « point épidémiologique en Ile-de-France du 29 avril 2020 » Published April 30, 2020.

9. A teacher informed us that a student's mother was hospitalized so she had to take care of her younger brother. Another student wrote: "I'm really sorry especially during this period of quarantine I have to manage my family because with the virus I find myself managing the house."

10. According to Paradox Labs "a typical $4 G$ mobile device gets a 5-12 Mbps download rate, compared to an average of over $50 \mathrm{Mbps}$ for broadband internet users." <https:// www.paradoxlabs.com/blog/mobile-vs-desktop-10-key-differences/>.

11. On the senseless nature of Covid-19, see Emmanuel Alloa's analysis "What if we were to consider, even if only for a moment, the truly senseless nature of what is happening to us? The global coronavirus pandemic is, in and of itself, intrinsically senseless and it has no inherent meaning. Its outbreak was neither necessary nor linear. A virus has no more intentionality than a tectonic plate, when the latter causes the waves of a tsunami as it moves." (Alloa 2020)

\section{INDEX}

Mots-clés: cours en ligne, Covid-19, environnement socio-économique, Pharmakon

Keywords: Covid-19, online courses, Pharmakon, socio-economic environment

\section{AUTHORS}

\section{GWEN LE COR}

Gwen Le Cor is Professor of American Literature and English for Specific Purposes at Université Paris 8 (France), and is a member of the TransCrit research lab. She co-chairs "Hydrology of Media" (HOM), a three-year research program (2020-2022) sponsored by EUR ArTeC (http://eurartec.fr/hom-hydrologie-des-medias/). HOM is an international transdisciplinary program which introduces a hydrologic approach to the relations between arts, science, technology, and the humanities. Her recent research focuses on hybridity and its figures, on literature-science nodes, and more generally on digital humanities. She is currently co-editing, two collective works, a first one with Margaux Coutherut on genres in ESP (Les genres en anglais de spécialité : définitions, méthodologies d'analyse et retombées pédagogiques) and a second one, with Everardo Reyes, exploring what making an image entails in the digital age (What makes an image? ISBN 978-2-37059-012-1) glecor@univ-paris8.fr

\section{MARGAUX COUTHERUT}

Margaux Coutherut is a lecturer in English grammar at the UFR LLCE-LEA of University Paris 8. She has also been the co-head of the LEA department since September 2019, which allows her to be in direct contact with students and has enabled her to observe the limits of distance learning. Her research themes are mainly the study and teaching of specialized written and oral textual genres. She is currently co-editing a book with Gwen Le Cor on genres in ESP (Les genres en anglais 
de spécialité : définitions, méthodologies d'analyse et retombées pédagogiques) for the Peter Lang collection Aspects linguistiques et culturels des discours spécialisés. margaux.coutherut@univparis8.fr 